\title{
Pharmacokinetics of diltiazem hydrochloride delay-onset sustained-release pellet capsules in healthy volunteers
}

\author{
Xi-Qing Yan', Zhi-Gang Chen², Rong-Liang Wang², Jun Yang1,*, Fang Ai ${ }^{3}$, \\ Yan-Juan Pan', Pei-Yong Qiu', Da-Xin Wang ${ }^{4}$ \\ ${ }^{1}$ College of Pharmacy, Xinxiang Medical University, Xinxiang, China, ${ }^{2}$ First affiliated Hospital of Xinxiang Medical University, \\ ${ }^{3}$ Department of Pediatric Surgery, First affiliated Hospital of Xinxiang Medical University, China, ${ }^{4}$ Clinical Medical College of \\ Yangzhou University, China
}

\begin{abstract}
The pharmacokinetics (PK) of ordinary tablets and sustained release capsules of diltiazem hydrochloride in human clinical trials had been studied. The PK of diltiazem hydrochloride delay-onset sustained-release pellet capsules, a new dosage form, has not been reported, although it is very important to clinical use. In this paper, we investigated the PK of diltiazem hydrochloride delay-onset sustained-release pellet capsules and the food influence in Chinese healthy volunteers. The PK parameters indicated that the diltiazem hydrochloride delay-onset sustained-release pellet capsules appeared marked characteristics of delayed and controlled release. An opened-label, randomized and parallel clinical trial was conducted in 36 Chinese healthy volunteers with single oral dose $(90 \mathrm{mg}, 180 \mathrm{mg}$ or $270 \mathrm{mg})$ and a multiple oral dose $\left(90 \mathrm{mg} \mathrm{d}^{-1} \times 6 \mathrm{~d}\right)$ administration. The effect of food on the PK of one single oral dose $(360 \mathrm{mg})$ was investigated in 24 healthy Chinese volunteers. Plasma diltiazem concentration was determined by reversed-phase high-performance liquid chromatography (RP-HPLC) and the main pharmacokinetic parameters were analyzed by PKSolver (Ver 2.0). All clinical studies were conducted in the Clinical Pharmacological Center (No. JDX1999064) of Xiangya Hospital Affiliated Central South University, China. The PK parameters suggested that the new formulation had marked characteristics of delayed and controlled release of diltiazem, and food intake did not alter significantly diltiazem pharmacokinetic parameters.
\end{abstract}

Uniterms: Diltiazem hydrochloride/delay-onset sustained-release pellet capsules/pharmacokinetics. Food/ingestion/effect in pharmacokinetic profile. High-performance liquid chromatography/quantitative analysis.

Embora a farmacocinética (PK) do cloridrato de diltiazem nas formas de comprimidos de liberação imediata e cápsulas de liberação modificada em ensaios clínicos já tenha sido relatada, a pesquisa da PK do cloridrato de diltiazem na forma de cápsulas com peletes de liberação retardada e sustentada ainda é muito importante. Neste trabalho, propusemos avaliar a farmacocinética do cloridrato de diltiazem administrado através desta nova forma farmacêutica em voluntários chineses sadios, assim como a influência da ingestão de alimentos neste perfil farmacocinético. Foi realizado um ensaio clínico aberto, randomizado e paralelo em 36 voluntários, que receberam dose oral única de $90 \mathrm{mg}, 180 \mathrm{mg}$ ou $270 \mathrm{mg}$ e dose múltiplas $(90 \mathrm{mg} / \mathrm{d} \times 6 \mathrm{~d})$ pela mesma via de administração. Para avaliar o efeito da ingestão de alimentos sobre a PK do diltiazem foi realizada a administração de dose única $(360 \mathrm{mg})$ em 24 voluntários chineses sadios. A concentração plasmática do diltiazem foi determinada por Cromatografia Liquida de Alta Eficiência em fase reversa (CLAE-FR) e os principais parâmetros farmacocinéticos foram analisados através do emprego do software PKSolver (Ver 2.0). O ensaio de farmacocinética clínica foi conduzido na clínica Pharmacological Center (No.JDX1999064) do Hospital de Xiangya, Central South University, China. Os parâmetros PK obtidos indicaram que a nova formulação de cápsulas de liberação retardada e sustentada de cloridrato de diltiazem possue marcantes características de liberação retardada e controlada do fármaco.

Unitermos: Cloridrato de diltiazem/peletes de liberação retardada e sustentada/farmacocinética. Alimentos/ingestão/efeito no perfil famacocinético. Cromatografia Líquida de Alta Eficiência/análise quantitativa.

*Correspondence: Jun Yang. College of Pharmacy, Xinxiang Medical Univer-

sity. Xinxiang, Henan 453003 - China. E-mail: bcd2009@126.com 


\section{INTRODUCTION}

Diltiazem, a calcium channel blocker of the benzodiazepine family, has been widely used for the treatment of angina pectoris (Chaffman, Brogden, 1985; Théroux et al., 1985; Hossack et al., 1981) and hypertension (Zhang et al., 2010; Bertere et al., 2009; Färbom et al., 2008), especially treatment of the hypertension with angina pectoris (Ezeugo, Glasser, 2009; Claas, Glasser, 2005). Pharmacodynamic studies showed that diltiazem might affect heart muscle by blocking influx of extracellular fluid calcium (Britt, 1985) and improving affinity of 1, 4-dihydropyridines for the $\mathrm{Ca}^{2+}$ channel (Glossmann et al., 1980).

Diltiazem has been introduced into clinical practice as the ordinary tablets and delay-onset capsules. The patient has to take the drug three times a day because the effective plasma concentration of diltiazem sustains so short time after the administration (Hekmatara et al., 2006; Mazzo et al., 1994). Although the sustained-release capsules of diltiazem hydrochloride keeps the diltiazem release and absorption slowly, the blood concentration is relatively low and flat, which is not suitable to the circadian rhythm of blood pressure (Weir, 1995; Scholz, 1997). So the extended and controlled release diltiazem form is better for the clinical requirement.

As a new form, diltiazem hydrochloride delay-onset sustained-release pellet is prepared by spraying diltiazem solution onto the surface of celpheres and then coating with hydroxy propyl methyl cellulose as swelling layer and Surelease as coating layer (Dey et al., 2008). There are two pellet kinds depending on adjusting the proportion of the surface macromolecular layer: one is a rapid release pellet after a long certain delayed time, and the other is an extended release pellet after a long certain delayed time. The two pellet kinds that are loaded in one single capsule ensure to delay the release of the active ingredient effecting in sufficient amount and extend for enough time. The delayed drug release is compatible with the chronopharmacologic drug delivery systems (Smolensky et al., 2007). These capsules delay the release of diltiazem for 4-6 h and be effectively compatible with the circadian variation of the disease.

The pharmacokinetics (PK) of ordinary tablets and sustained capsules of diltiazem hydrochloride in human trials were already studied (Yeung et al., 1999; Sista et al., 2003; Caillé et al., 1991; Weiner et al., 1986). The PK of diltiazem hydrochloride delay-onset sustained-release pellet capsules with the delayed and controlled drug release is very important for this new medicine, although it has not been reported. The aim of the present work was to evaluate the PK of diltiazem hydrochloride delay-onset sustained- release pellet capsules and the influence of food on drug absorption in Chinese healthy volunteers, via establishing an analytical method to quantify human plasma diltiazem concentration by reversed-phase high-performance liquid chromatography (RP-HPLC).

\section{MATERIAL AND METHODS}

\section{Drug and reagents}

Four dosages ( $90 \mathrm{mg}, 180 \mathrm{mg}, 270 \mathrm{mg}$ and $360 \mathrm{mg}$ ) of diltiazem hydrochloride delay-onset sustained-release pellet capsules (Batch: 111202, Specifications: $90 \mathrm{mg} /$ capsule) for single, multiple and food-effect oral administrations were made. Each capsule was contained of two kinds of pellets consisted of HPMC and Surelease, in which one was the short delayed release and the other was the long delayed release, respectively. Diltiazem hydrochloride reference substance (Batch: 070223-201101) was purchased from Chinese National Institutes for Food and Drug Control with the purity of diltiazem more than 98.4\%. Alprazolam reference substance (Batch: 0912) was obtained from State Narcotics Laboratory, China, with the purity of alprazolam more than $99.8 \%$. Acetonitrile (HPLC grade) was purchased from Caledon Company, Canada. Double Distilled water and other reagents were analytical grade.

\section{Instruments}

The HPLC system was an Agilent Chemistation Rev.A.08.03 System (HPLC1100, Agilent, American) equipped with a G1313A quaternary pump, a vacuum degasser, a G-1316 column oven, and a G1315B photodiode array detector. Low speed centrifuge (80-20) was from Shanghai Medical Instrument Co., Ltd. (Shanghai, China).

\section{Test subjects}

Thirty six Chinese volunteer, half male and half female, with mean age of $23.4 \pm 3.7$ (18-27 years), mean weight of $64.5 \pm 5.8 \mathrm{~kg}$ with body mass index (BMI) $23.4-24.6 \mathrm{~kg} \mathrm{~m}^{-2}$, and mean height of $167.0 \pm 5.8 \mathrm{~cm}$ were enrolled in the study. All the subjects were confirmed to be healthy by physical examination, passing through the clinical laboratory tests, and screening the medical histories. None of the subjects had any surgery or took any alterative medications other than diltiazem hydrochloride. No medications were taken for at least two weeks before the study. Tobacco, alcohol, beverage containing alcohol and caffeine were forbidden $48 \mathrm{~h}$ before the study and 
during the study. During process of the single and multiple dose clinical studies, all subjects were fed with the unified light foods diet and confined in special wards. In the food-effect study, the high fat food diet used was based on the Guideline Recommendation of US FDA but adopted to Chinese dietary habit include: one fried egg, pork (fat: lean=2:1) $75 \mathrm{~g}$, rape $100 \mathrm{~g}$, colza oil $20 \mathrm{ml}$ for cooking, the steamed bread $100 \mathrm{~g}$ and rice gruel $150 \mathrm{~mL}$ as staple food. The above Chinese food could provide approximately 1118 calories. Following the Guidance of Helsinki Declaration, all subjects signed the informed consent. The study protocol was approved by Ethic Committee of Xiangya Hospital Affiliated Central South University, China (Protocol JDX1999064).

\section{Study design}

\section{Single dose study}

An opened-label, randomized, parallel and single dose clinical study was carried out in 36 Chinese healthy volunteers. The subjects were equally (12 subjects one group, male and female equalization) divided to three groups as A, B, and C, and were administrated with specified doses of 90, 180 and $270 \mathrm{mg}$ diltiazem respectively. All subjects were supplied with unified light diet, and then fasted but water supplied overnight before the drug administration and given corresponding diltiazem hydrochloride delay-onset sustained-release pellet capsules (Group A, 1 capsule; Group B, 2 capsules, Group C, 3 capsules) with $240 \mathrm{~mL}$ warm water for oral administration. And food was withheld for an additional 4 hours. Venous blood $(5 \mathrm{ml})$ for pharmacokinetics study was collected into the heparinized tubes before drug administration ( 0 hour) and at $0.25,0.5,1,1.5,2,3,4,5,6,7,8,9,10,12,24$, and $36 \mathrm{~h}$ after drug oral administration. The blood was immediately centrifuged for $10 \mathrm{~min}$ at $3000 \mathrm{rpm} \cdot \mathrm{min}^{-1}$ to separate the plasma, which then was frozen and stored at $-40{ }^{\circ} \mathrm{C}$ for assay. Adverse events of each subject were carefully observed and recorded during the study.

\section{Multiple dose study}

Multiple dose studies were carried out in Group A (12 volunteers) 14 days after the single dose study when the wash-out period passed. All subjects were fasted but water supplied overnight before each drug administration, and then given corresponding diltiazem hydrochloride delay-onset sustained-release pellet capsules (one capsule, $90 \mathrm{mg}$ ) with $240 \mathrm{~mL}$ warm water at 8:00 in the next morning. It was continued the drug administration (one capsule) for 6 days. Venous blood $(5 \mathrm{~mL})$ for pharmacokinetics study was collected into the heparinized tubers before drug administration ( 0 hour) in the $4^{\text {th }}, 5^{\text {th }}, 6^{\text {th }}$ day and after oral administration at $0.25,0.5,1,1.5,2,3,4,5,6,7,8,9,10$, 12,24 and $36 \mathrm{~h}$ in the $6^{\text {th }}$ day. The blood was immediately centrifuged for $10 \mathrm{~min}$ at $3000 \mathrm{r} \cdot \mathrm{min}^{-1}$ to separate the plasma, which was frozen and stored at $-40{ }^{\circ} \mathrm{C}$ for assay. Adverse events of each subject were carefully observed and recorded during the study.

\section{Food-effect study}

The effect of food on corresponding diltiazem hydrochloride delay-onset sustained-release pellet capsules was carried out in group B and C (24 volunteers) after the single dose study. A randomized, open-label, two-period crossover method was designed to take a single dose of diltiazem (360 mg, 4 capsules) with a 14 days wash-out period between the two occasions. Subjects were admitted to ward on the day before the drug administration. From 7:00 pm after dinner to the dosing on the day, subjects were not allowed to eat any food expect water. Subjects were randomized to treat (the delay-onset sustained-release pellet capsules $360 \mathrm{mg}$ without food (fasting condition), or with high-fat food (fed). After a 14-days washout period, subjects were crossed over to the alternate treatment. All subjects received the same lunch and supper following drug administration. After administration, the subjects in the fasted group remained fasting for 4 hours. Water was allowed ad libitum throughout the study period except for 4 hours pre- and post-study drug administration. Strenuous exercise was not permitted during the 36 -hour postdose monitoring period. Blood $(5 \mathrm{~mL})$ was collected into heparinized tubes before and at $0.25,0.5,1,1.5,2,3,4,5$, $6,7,8,9,10,12,24$ and 36 hours after drug administration. The blood was immediately centrifuged for $10 \mathrm{~min}$ at $3000 \mathrm{r} \cdot \mathrm{min}^{-1}$ to separate the plasma, which was frozen and stored at $-40{ }^{\circ} \mathrm{C}$ for assay.

\section{Analysis of blood samples \\ - Blood preparation}

To $1 \mathrm{~mL}$ of spiked plasma sample, $30 \mu \mathrm{L}$ of a solution containing alprazolam $\left(2.44 \mu \mathrm{g} \cdot \mathrm{mL}^{-1}\right.$, internal standard) and $1 \mathrm{~mL}$ of sodium hydroxide solution $\left(0.1\right.$ mol. $\left.\mathrm{L}^{-1}\right)$ were added, and then the obtained mixture was vortex-mixed for $1 \mathrm{~min}$. An aliquot of the hexane: trichloromethane: isopropanol $(60: 40: 5)(5 \mathrm{~mL})$ was then added to the mixture, vortex-mixed for another $2 \mathrm{~min}$ and then centrifuged at $3000 \mathrm{rpm}$ for $10 \mathrm{~min}$. The supernatant was collected and evaporated to dryness under a nitrogen stream at $-40{ }^{\circ} \mathrm{C}$. The residues were reconstituted with $100 \mu \mathrm{L}$ of the mobile phase, respectively, and an aliquot of $50 \mu \mathrm{L}$ of each sample was injected to HPLC for LC-UV analysis. 
- RP-HPLC conditions

The blood was separated on Gemini ODS $\mathrm{C}_{18}$ $(4.6 \mathrm{~mm} \times 550 \mathrm{~mm}, 5 \mu \mathrm{m})$ column and detected at the UV wavelength of $215 \mathrm{~nm}$. The HPLC separation temperature was set at $35{ }^{\circ} \mathrm{C}$. The mobile phase was made up of acetonitrile: $0.08 \%$ triethylamine solution 37: 63 (v/v) (adjusted to $\mathrm{pH}$ 3.01-3.06 using phosphoric acid) at a flow rate at $1.2 \mathrm{~mL} \cdot \mathrm{min}^{-1}$.

\section{Method validation}

- Calibration curve and limit of quantification

The RP-HPLC analytical method was validated by evaluated linearity of standard curve, intra-day and interday precision and accuracy, and recovery of diltiazem extracted in plasma. The calibration curve was constructed using seven different concentration levels of diltiazem without 0 .

The limit of the quantification was defined as the lowest amount of the analyte in plasma that was quantitatively determined with suitable precision $(\leq 20 \%)$ of the true concentration.

- Recovery, accuracy and precision

To determine the absolute recovery of diltiazem in plasma, three different concentration levels at 10.1, 80.8, and $646.4 \mathrm{ng} . \mathrm{mL}^{-1}$ of diltiazem were obtained by spiked diltiazem into the blank plasma, in which the diltiazem level was so low that was difficult to be measured, with six replicates for each concentration, and then the samples were extracted and analyzed by the RP-HPLC as described above. The absolute recoveries of diltiazem were obtained by dividing peak areas of extracted samples by those of corresponding spiked standard solution in the extracted blank plasma.

Accuracy and precision of the method were assessed by intra-day and inter-day analysis of six replicates for each concentration at 3 different concentration levels (10.1, 80.8 , and $646.4 \mathrm{ng} . \mathrm{mL}^{-1}$, respectively). The coefficient of variation $(\mathrm{CVs})$ at each concentration level was expressed as precision. The intra-day and inter-day precision was analyzed by one-way analysis of variance (ANOVA) method.

- Sample stability tests

The stability tests were to measure the concentrations of the spiked diltiazem in the blank plasma which were placed on the laboratory desk at room temperature for $24 \mathrm{~h}$, which were frozen and defrosted for 1 to 3 times, or which were stored at frozen condition for 0 to 28 days.

- Quality control samples

Diltiazem was spiked into the blank plasma to reach the final concentration levels at $10.1,80.8$, and 646.4 ng. $\mathrm{mL}^{-1}$, respectively as quality control samples. The quality control concentrations should cover the concentrations of the target analyses.

\section{The data processing and statistical analysis}

Plasma diltiazem concentration profiles of $36 \mathrm{sub}-$ jects were presented as mean \pm standard deviation (SD). Main pharmacokinetics parameters were calculated for each subject. $\mathrm{T}_{\max }$ and $\mathrm{C}_{\max }$ were obtained directly from the observed data. Plasma concentrations that lower than the lower limit of quantification (LLOQ) were assigned as a value of zero for the calculation of plasma concentrations and pharmacokinetic parameters. All the PK parameters were calculated by the PK-Solver 2.0 (China Medicine University, China).

\section{RESULTS}

\section{Method validation}

\section{Chromatographic behaviors}

The typical chromatograms of diltiazem were shown in Figure 1. The analyte and Internal standard (IS) were separated very well, where the retention time of diltiazem and IS was at $6.8 \mathrm{~min}$ and $9.3 \mathrm{~min}$, respectively. It was not found any endogenous interference peaks on their chromatograms.

\section{Linearity of the calibration curve and the limit of quantification}

The diltiazem was added into blank plasma to obtain the concentrations of standard solutions at 10.1, 20.2, 40.4, 80.8, 161.6, 323.2 and $646.6 \mathrm{ng} \cdot \mathrm{mL}^{-1}$. The samples were prepared and analyzed by RP-HPLC as above. A good linear correlations regression equation of diltiazem was fitted as: $\mathrm{Y}=(0.00586) \mathrm{X}+0.02481, \mathrm{r}=0.9990$, (where $\mathrm{X}$ was the plasma concentration of diltiazem hydrochloride, and Y was the peak area ratio of IS diltiazem hydrochloride). The calibration curve linearity of diltiazem hydrochloride was from the range of 10.1 to $646.4 \mathrm{ng} . \mathrm{mL}^{-1}$.

\section{Recovery, accuracy and precision}

The absolute recoveries of diltiazem extracted in plasma were $82.9 \pm 18.4,94.6 \pm 14.9$ and $70.5 \pm 7.1 \%$, respectively, corresponding for the three concentration levels of 10.1, 80.8, and $646.4 \mathrm{ng} . \mathrm{mL}^{-1}$ listed in Table I. The recovery of IS was $97.2 \pm 5.4 \%$. The absolute recovery rates of this method were suitable for the PK studies of diltiazem in human plasma (Werghese et al., 1983). 
TABLE I - The recovery rates of diltiazem and internal standard

\begin{tabular}{|c|c|c|c|c|c|c|c|c|c|}
\hline \multirow{3}{*}{ samples } & \multirow{3}{*}{$\begin{array}{l}\text { concentration } \\
\left(\text { ng. } \mathrm{mL}^{-1}\right)\end{array}$} & \multicolumn{6}{|c|}{ peak area } & \multirow{3}{*}{$\begin{array}{l}\text { mean } \\
\text { recovery } \\
(\%)\end{array}$} & \multirow{3}{*}{ RSD (\%) } \\
\hline & & \multicolumn{5}{|c|}{$\mathrm{A}$} & \multirow{2}{*}{ B } & & \\
\hline & & 1 & 2 & 3 & 4 & 5 & & & \\
\hline \multirow[t]{3}{*}{ diltiazem } & 10.1 & 14.3 & 12.2 & 11.4 & 11.7 & 17.3 & 16.2 & 82.9 & 18.4 \\
\hline & 80.8 & 118.4 & 117.1 & 84.9 & 91.4 & 96.6 & 107.5 & 94.6 & 14.9 \\
\hline & 646.4 & 657.5 & 621.5 & 713.8 & 679.3 & 596.9 & 927.5 & 70.5 & 7.1 \\
\hline alprazolam & 2.44 & 153.6 & 169.9 & 160.2 & 169.3 & 176.2 & 170.7 & 97.2 & 5.4 \\
\hline
\end{tabular}

The result of the peak area of the diltiazem dissolved in plasma was marked as A (repeated for five times); the peak area of diltiazem dissolved in mobile phase was marked as B.

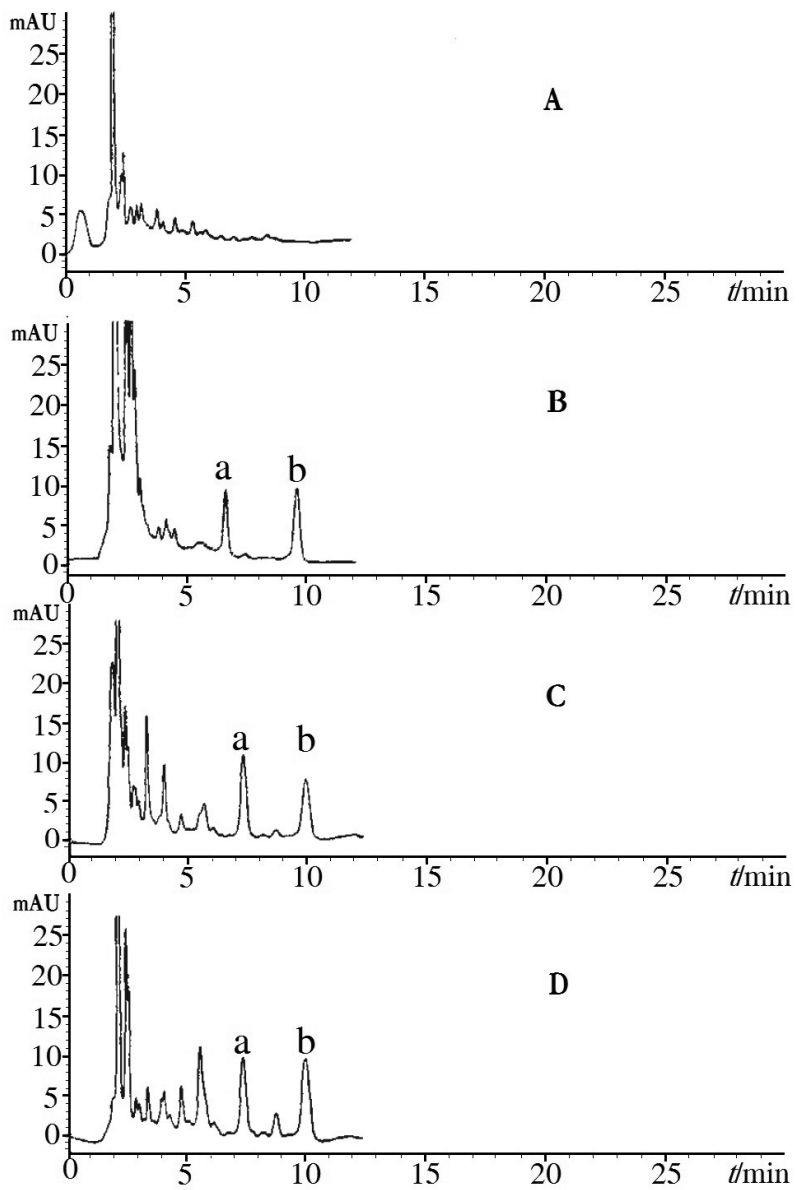

FIGURE 1 - Typical HPLC chromatograms of diltiazem in plasma. A: chromatogram of blank plasma; B: chromatogram of the mixed standard diltiazem $(0.1 \mu \mathrm{g} / \mathrm{mL})$ (a) and alprazolam $(0.1 \mu \mathrm{g} / \mathrm{mL})(\mathrm{b}) ; \mathrm{C}$ : chromatogram of blank plasma spiked with diltiazem $(0.1 \mu \mathrm{g} / \mathrm{mL})$ (a) and alprazolam $(0.1 \mu \mathrm{g} / \mathrm{mL})(\mathrm{b}) ; \mathrm{D}$ : chromatogram of diltiazem $(0.1 \mu \mathrm{g} / \mathrm{mL})$ (a) plasma samples mixed with alprazolam $(0.1 \mu \mathrm{g} / \mathrm{mL})(\mathrm{b})$.

Table II was the precision and accuracy of intraday and inter-day. The results showed the precision of intra-day analysis of diltiazem spiked in the blank plasma at three different concentration levels were $6.2 \%, 5.6 \%$, $2.7 \%$, respectively, and that of the inter-day were $7.3 \%$, $3.0 \%$ and $4.4 \%$, respectively. These data demonstrated high precision and accuracy of the method.

TABLE II - Precision and accuracy of the analytical method ( $\mathrm{n}=6$ )

\begin{tabular}{lcc}
\hline \multirow{2}{*}{$\begin{array}{l}\text { Concentration } \\
\left.\text { (ng.mL } \mathrm{mL}^{-1}\right)\end{array}$} & \multicolumn{2}{c}{ Precision $(\mathrm{RSD} / \%)$} \\
\cline { 2 - 3 } & Intra-day & Inner-day \\
\hline 10.1 & 6.2 & 7.3 \\
80.8 & 5.6 & 3.0 \\
646.4 & 2.7 & 4.4 \\
\hline
\end{tabular}

\section{Sample stability}

- Stability of plasma diltiazem at room temperature

The blank plasma with diltiazem levels at 10.1, 80.8, or $646.4 \mathrm{ng} . \mathrm{mL}^{-1}$ was kept at room temperature for 24 hours. The RSD at $0,2,6,12$, or $24 \mathrm{~h}$ was not more than $11.1 \%$ (LLOQ sample), $1.8 \%$, and $2.1 \%$, respectively.

- Stability of plasma diltiazem after freeze-thaw circles

The blank plasma with diltiazem levels at 10.1,80.8, or $646.4 \mathrm{ng} . \mathrm{mL}^{-1}$ was frozen at $-40{ }^{\circ} \mathrm{C}$ and followed three freeze-thaw cycles. The RSD was not more than $7.6 \%$ (LLOQ sample), $3.2 \%$, and $1.7 \%$, respectively.

- Stability of plasma diltiazem after frozen storage The blank plasma with diltiazem levels at 10.1, 80.8, or 646.4 ng. $\mathrm{mL}^{-1}$ was analyzed after the samples were frozen at $-20^{\circ} \mathrm{C}$ for 0 to 28 days. The RSD was not more than $19.5 \%$ (LLOQ sample), $6.1 \%$, and $4.7 \%$, respectively.

These results showed that the plasma diltiazem was quite stable during the whole PK studies. 
TABLE III - Pharmacokinetic parameters of single oral dose $($ mean $\pm \mathrm{SD}, \mathrm{n}=12)$

\begin{tabular}{lccc}
\hline Parameter & \multicolumn{3}{c}{ Dose/mg } \\
\cline { 2 - 4 } & 90 & 180 & 270 \\
\hline $\mathrm{T}_{\max } / \mathrm{h}$ & $11.15 \pm 1.10$ & $11.76 \pm 1.25$ & $11.48 \pm 1.03$ \\
$\mathrm{C}_{\max } / \mathrm{ng}_{\mathrm{m}} \mathrm{mL}^{-1}$ & $128.26 \pm 22.61$ & $162.69 \pm 32.24$ & $191.00 \pm 40.26$ \\
$\beta / \mathrm{h}^{-1}$ & $0.0479 \pm 0.013$ & $0.0480 \pm 0.017$ & $0.0466 \pm 0.011$ \\
$\mathrm{~T}_{1 / 2 \beta} / \mathrm{h}$ & $14.47 \pm 0.42$ & $14.41 \pm 2.32$ & $14.89 \pm 1.16$ \\
$\mathrm{~T}_{\text {lag }} / \mathrm{h}$ & $4.85 \pm 0.51$ & $4.81 \pm 0.73$ & $4.58 \pm 0.42$ \\
$\mathrm{AUC}$ & /ng.mL.h $\mathrm{h}^{-1}$ & $3511.52 \pm 324.90$ & $4245.90 \pm 468.82$ \\
$\mathrm{AUC}$ & $/ \mathrm{ng} \cdot \mathrm{mL} \cdot \mathrm{h}^{-1}$ & $4307.71 \pm 628.42$ & $5341.92 \pm 861.74$ \\
$\mathrm{CL} / \mathrm{F} / \mathrm{mL} \cdot \mathrm{h}^{-1}$ & $2597.97 \pm 313.22$ & $41786 \pm 2143$ & $50543 \pm 10723$ \\
$\mathrm{~V} / \mathrm{F} / \mathrm{L}$ & $3131.61 \pm 765.71$ & $870.541 \pm 738$ & $1084.613 \pm 91.9$ \\
\hline
\end{tabular}

\section{Pharmacokinetics}

Diltiazem was quite well tolerated, in which neither serious unexpected events occurred nor drop-out in the volunteers during the study. All volunteers were in good condition in the clinical trials.

\section{Single dose trial}

The mean plasma concentration-time profiles of 36 healthy volunteers in single oral administration with the dose of $90 \mathrm{mg}, 180 \mathrm{mg}$, or $270 \mathrm{mg}$ of diltiazem hydrochloride delayed-onset sustained-release pellet capsules were shown in Figure 2. The main PK parameters were summarized in Table III. Mean $\mathrm{C}_{\max }$ values were $128.26 \pm$ $22.61,162.69 \pm 32.24$, and $191.00 \pm 40.26 \mathrm{ng} \cdot \mathrm{mL}^{-1}$. The corresponding $\mathrm{T}_{\max }$ values were $11.15 \pm 1.10,11.76 \pm$ 1.25 , and $11.48 \pm 1.03$ hours, respectively and $\mathrm{t}_{1 / 2 \beta}$ values were $14.47 \pm 0.42,14.41 \pm 2.32$, and $14.89 \pm 1.16$ hours;

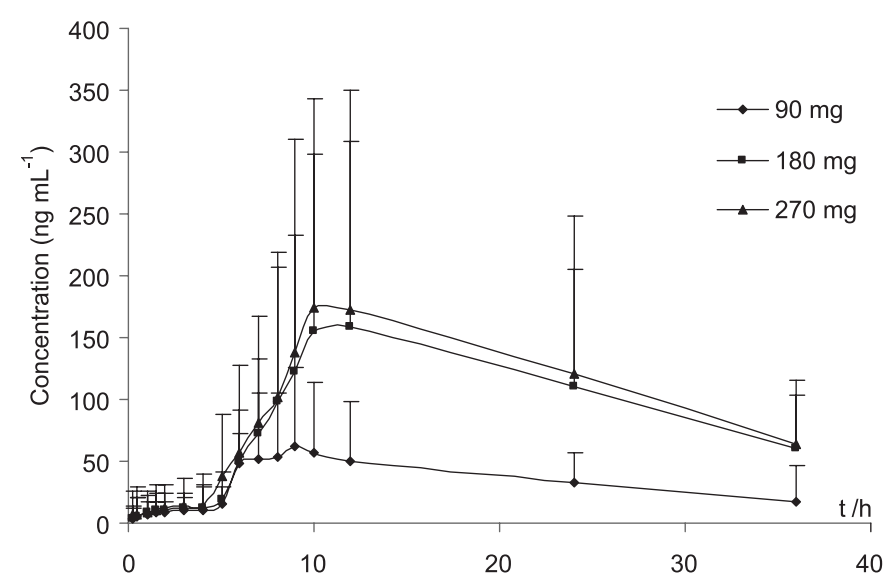

FIGURE 2 - Plasma concentration-time curves of single oral dose $(90,180$ or $270 \mathrm{mg})$ of diltiazem hydrochloride delayedonset sustained-release pellet capsules (mean $\pm \mathrm{SD}, \mathrm{n}=12$ ).
The $\mathrm{T}_{\text {lag }}$ values were $4.85 \pm 0.51,4.81 \pm 0.73,4.58 \pm 0.42$ hours. The $\mathrm{AUC}_{36}$ were $2597.97 \pm 313.22,3511.52 \pm$ 324.90, and $4245.90 \pm 468.82$ ng.h.mL ${ }^{-1}$, while the $\mathrm{AUC}_{\infty}$ were $3131.61 \pm 765.71,4307.71 \pm 628.42$, and $5341.92 \pm$ 861.74 ng.h. $\mathrm{mL}^{-1}$ respectively.

\section{Multiple-dose trials}

The mean plasma concentration-time profiles of multiple oral doses $(90 \mathrm{mg}$ ) of diltiazem hydrochloride delayed-onset sustained-release pellet capsules in $6^{\text {th }}$ day were shown in Figure 3. Considering the factual dosing interval was $24 \mathrm{~h}$, the PK parameters that were calculated by PKSolver 2.0 as Table IV. The mean $\mathrm{C}_{\text {mas.ss }}$ value was $181.33 \pm 23.09$ ng. $\mathrm{mL}^{-1}$, the corresponding $\mathrm{T}_{\max }$ value was $10.39 \pm 1.32$ hour and $t_{1 / 2 \beta}$ was $14.38 \pm 0.72$ hour. The $\mathrm{C}_{\text {min,ss }}$ was $44.08 \pm 3.06 \mathrm{ng} \cdot \mathrm{mL}^{-1}$ and the $\mathrm{AUC}_{0 \sim 24, \mathrm{ss}}$ was $3127.61 \pm$ 233.37 ng.h.mL $\mathrm{mL}^{-1}$. The oral clearance $(\mathrm{CL} / \mathrm{F})$ of multipledose group was $28775 \pm 216 \mathrm{~mL} \cdot \mathrm{h}^{-1}$.

TABLE IV - Pharmacokinetic parameters of multiple oral doses $($ mean $\pm \mathrm{SD}, \mathrm{n}=12)$

\begin{tabular}{|c|c|}
\hline Parameter & $90 \mathrm{mg}$ \\
\hline$\overline{\mathrm{T}_{\text {lag }} / \mathrm{h}}$ & $4.419 \pm 0.012$ \\
\hline $\mathrm{T}_{\max } / \mathrm{h}$ & $10.39 \pm 1.32$ \\
\hline $\mathrm{C}_{\max , \mathrm{ss}} / \mathrm{ng} \cdot \mathrm{mL}^{-1}$ & $181.33 \pm 23.09$ \\
\hline $\mathrm{C}_{\mathrm{min}, \mathrm{ss}} / \mathrm{ng} \cdot \mathrm{mL}^{-1}$ & $44.08 \pm 3.06$ \\
\hline $\mathrm{C}_{\mathrm{ss} \text { average }} / \mathrm{ng} \cdot \mathrm{mL}^{-1}$ & 132.48 \\
\hline$\beta / h^{-1}$ & $0.048 \pm 0.027$ \\
\hline $\mathrm{T}_{1 / 2 \beta} / \mathrm{h}$ & $14.38 \pm 0.72$ \\
\hline $\mathrm{AUC}_{0 \sim 24, \mathrm{ss}} / \mathrm{ng} \cdot \mathrm{mL} \cdot \mathrm{h}^{-1}$ & $3127.61 \pm 233.37$ \\
\hline $\mathrm{CL} / \mathrm{F} / \mathrm{mL} \cdot \mathrm{h}^{-1}$ & $28775 \pm 216$ \\
\hline $\mathrm{V} / \mathrm{F} / \mathrm{L}$ & $599.499 \pm 31.3$ \\
\hline DF(degree of fluctuation) & $1.06 \pm 0.12$ \\
\hline
\end{tabular}




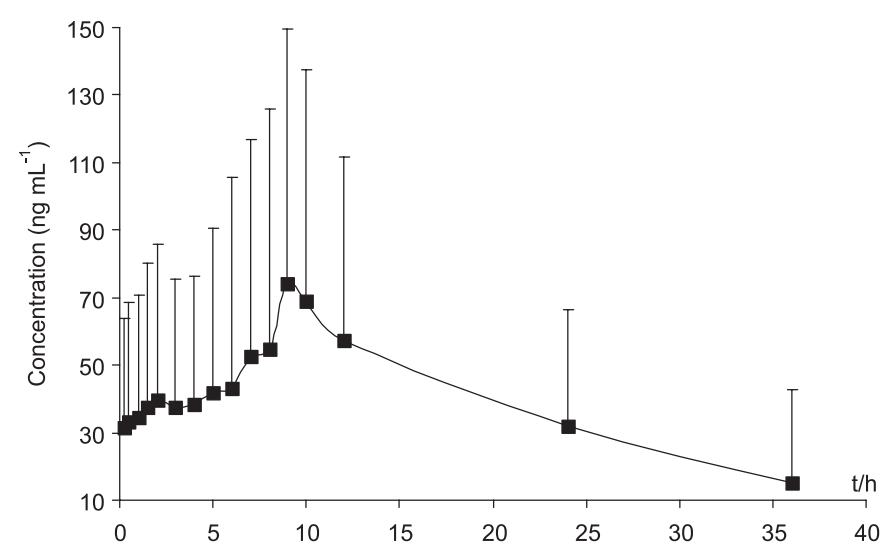

FIGURE 3 - Mean plasma concentration-time profiles of multiple oral dose $(90 \mathrm{mg})$ of diltiazem hydrochloride delayonset sustained-release pellet capsules $\left(6^{\text {th }}\right.$ day) (mean $\pm \mathrm{SD}$, $\mathrm{n}=12)$.

\section{Food-effects trials}

The mean plasma concentration-time profiles of high calories food-effects on diltiazem hydrochloride delayed-onset sustained-release pellet capsules (360 $\mathrm{mg}$ ) and parameters of fasted condition in plasma were shown in Figure 4. The corresponding PK parameters in steady-state were reported in Table V. The Mean $\mathrm{C}_{\max }$ values were $216.09 \pm 34.68$ and $206.51 \pm 41.23 \mathrm{ng} . \mathrm{mL}^{-1}$; the corresponding $\mathrm{T}_{\max }$ values were $11.8 \pm 1.8$ and $11.6 \pm$ 2.1 hours; the $\mathrm{t}_{1 / 2 \beta}$ were $16.1 \pm 4.2$ and $14.3 \pm 5.7$ hours; and the $\mathrm{AUC}_{36}$ were $4663.8 \pm 1521.3$ and $4530.6 \pm 1671.2$ ng.h.mL ${ }^{-1}$, while the $\mathrm{AUC}_{\infty}$ were $5851.3 \pm 1625.7$ and $5622.9 \pm 1756.2$ ng.h.mL ${ }^{-1}$. The oral clearance (CL/F) of multiple-dose group from fed and fasted group were 61.5 \pm 8.72 and $64.2 \pm 1.31 \mathrm{~mL} . \mathrm{h}^{-1}$, respectively.

TABLE V - Pharmacokinetic parameters of food-effect on delayed-onset sustained-release pellet capsules

\begin{tabular}{|c|c|c|}
\hline \multirow{2}{*}{ Parameter } & \multicolumn{2}{|c|}{ Dose/360 mg } \\
\hline & fasted & fed \\
\hline $\mathrm{T}_{\max } / \mathrm{h}$ & $11.6 \pm 2.1$ & $11.8 \pm 1.8$ \\
\hline $\mathrm{C}_{\max } / \mathrm{ng} \cdot \mathrm{mL}^{-1}$ & $206.51 \pm 41.23$ & $216.09 \pm 34.68$ \\
\hline$\beta / h^{-1}$ & $0.048 \pm 0.021$ & $0.043 \pm 0.019$ \\
\hline $\mathrm{T}_{1 / 2 \beta} / \mathrm{h}$ & $14.3 \pm 5.7$ & $16.1 \pm 4.2$ \\
\hline $\mathrm{T}_{\mathrm{lag}} / \mathrm{h}$ & $4.92 \pm 0.82$ & $4.80 \pm 0.56$ \\
\hline $\mathrm{AUC}_{36} / \mathrm{ng} \cdot \mathrm{mL} \cdot \mathrm{h}^{-1}$ & $4530.6 \pm 1671.2$ & $4663.8 \pm 1521.3$ \\
\hline $\mathrm{AUC}_{\infty} / \mathrm{ng} \cdot \mathrm{mL} \cdot \mathrm{h}^{-1}$ & $5622.9 \pm 1756.2$ & $5851.3 \pm 1625.7$ \\
\hline $\mathrm{CL} / \mathrm{F} / \mathrm{mL} \cdot \mathrm{h}^{-1}$ & $64.2 \pm 1.31$ & $61.5 \pm 8.72$ \\
\hline
\end{tabular}

Mean $\pm \mathrm{SD}, \mathrm{n}=12$; the fasted and fed were the abbreviated of fasted food condition and feed condition respectively.

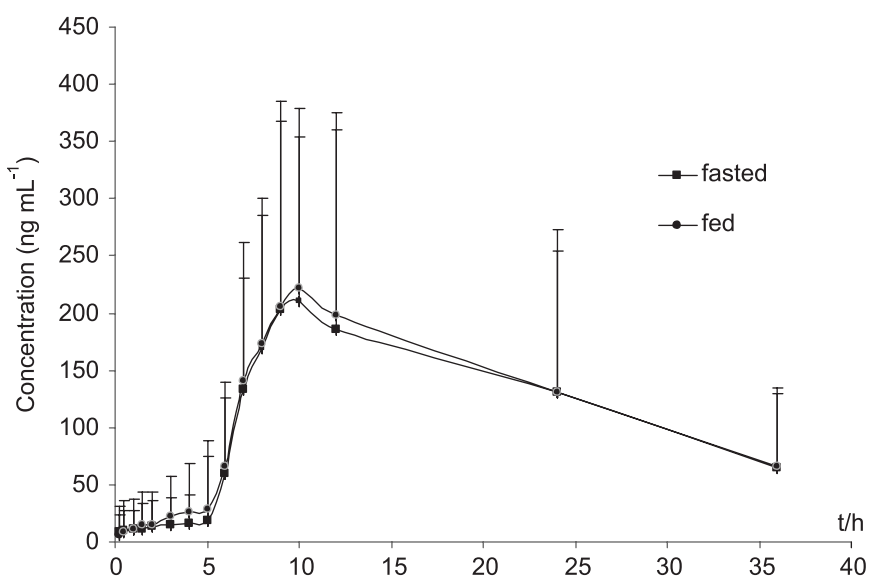

FIGURE 4 - Plasma concentration-time curves of food-effect on diltiazem hydrochloride delayed-onset sustained-release pellet capsules ( 4 capsules, $360 \mathrm{mg}$ total) (mean $\pm \mathrm{SD}, \mathrm{n}=12$ ).

\section{DISCUSSION}

Several RP-HPLC methods for measuring human plasma diltiazem concentration have been reported (Sultana et al., 2010; Zargh et al., 2005). The method that sodium hydroxide was used as alkaline extraction solution remarkably increased the extraction rates of diltiazem from plasma sample (Höglund, Nilsson, 1987). This method was simple and sensitive in short analysis time for diltiazem determination in plasma. The lower limit of quantification (LLOQ) (10.1 ng. $\mathrm{mL}^{-1}$ ) for the plasma diltiazem concentration was suitable for the detection in this experiment following the FDA advice ( RSD $<20 \%$ ).

Compared with the PK parameters obtained from the same oral dose of tablets, the main PK parameters of $t_{\max }$, $\mathrm{C}_{\text {max }}, \mathrm{AUC}_{\mathrm{t}}$ and $\mathrm{t}_{1 / 2}$ of diltiazem hydrochloride delayedonset sustained-release pellet capsules in three single oral dose groups were much higher in the present study than the corresponding PK parameters reported in the previous literatures (Murata et al., 1989; Turner, 2002).

The parameters of $\mathrm{AUC}_{36}$ and $\mathrm{AUC}_{\infty}$ in group $\mathrm{B}$ with the oral administration of $180 \mathrm{mg}$ single dose were higher than those in group A with $190 \mathrm{mg}$, and lower than those in group $\mathrm{C}$ with $270 \mathrm{mg}$. The $\mathrm{T}_{\text {lag }}$ (about 5 hours) indicted that the diltiazem release from the pellets was a delayed release character. Moreover, the point deviation in the concentration-time curves should be attributed to big individual differences among the volunteers.

Theoretically, the main PK parameters obtained from single dose and multiple doses are in accordance with each other, of which the multiple parameters could be calculated out by single. In this process, the multiple parameters of $\mathrm{t}_{\text {max }}, \mathrm{C}_{\text {max,ss }}, \mathrm{C}_{\text {min,ss, }} \mathrm{C}_{\text {ss,average }}$ and $\mathrm{AUC}_{0 \sim 24 \mathrm{~h}, \mathrm{ss}}$ calculated from single were $5.95 \mathrm{~h}, 182.24 \mathrm{ng} \cdot \mathrm{mL}^{-1}, 43.34 \mathrm{ng} \cdot \mathrm{mL}^{-1}$, 
130.48 ng. $\mathrm{mL}^{-1}, 3131.61 \mathrm{ng} . \mathrm{mL}^{-1}$ respectively, which were well coincided with the corresponding actual values listed as Table IV. The only exceptional parameter was that the real multiple $\mathrm{t}_{\max }$ was $10.39 \mathrm{~h}$, which was thought as the total of $\mathrm{t}_{\mathrm{lag}}(4.41 \mathrm{~h})$ and the calculated $\mathrm{t}_{\max }$ by single $(5.95 \mathrm{~h})$. Response to the reported pharmacokinetic parameters of the same multiple oral dose, the present results showed that the time to maximum plasma concentration $\left[\mathrm{t}_{\max }=(10.39 \pm 1.32) \mathrm{h}\right]$ was prolonged significantly. However, the elimination half-life $\left(\mathrm{t}_{1 / 2 \beta}=14.38 \pm 0.72 \mathrm{~h}\right)$ remained extending (Lefebvre et al., 1994; Roberts et al., 1991; Ochs et al., 1984).

A dose of $360 \mathrm{mg}$ diltiazem could be found using in clinical practice, thus a dumping dose in high fat food condition effect should be investigated. The comparisons of parameters $\mathrm{AUC}$ and $\mathrm{C}_{\text {max }}$ after taking delay-onset pellets of diltiazem in food and fasted state appeared only slight increase $\left(\mathrm{C}_{\max }\right.$ from 206.51 to $216.09 \mathrm{ng} . \mathrm{mL}^{-1} ; \mathrm{t}_{1 / 2 \beta}$ from 14.3 to $16.1 \mathrm{~h}$; $\mathrm{AUC}_{\infty}$ from 5622.9 to $5851.3 \mathrm{ng} . \mathrm{mL}^{-\mathrm{h}^{-1}}$ ), but the $\mathrm{T}_{\max }$ of fed (11.8 \pm 1.8 hour) almost appeared equal to that of fasted condition (11.6 \pm 2.1 hour). That means the delay-onset dosage form was well tolerated under food and fast condition. No marked difference was observed in the PK parameters and curves. The data showed that the delayed-onset dosage form could be administrated without regards of food effect.

The diltiazem hydrochloride delayed-onset release capsules were mainly used to treat the blood pressure and cardiac disease. Indeed, the prominent 24-hour variation in the occurrence of a variety of acute cardiovascular events, such as myocardial infarction, angina pectoris, cardiac arrest and sudden cardiac death have been shown to be closely related to the circadian blood pressure pattern of hypertensive subjects (Portaluppi et al., 1999). The objective of the pellets capsules was to adject the diltiazem release to vary with the variation of blood pressure in 24-hour time. Such model could match the circadian pattern of blood pressure characterized by a low span associated with sleep, rest, or inactivity, followed by a steep rise over a 4-hour period that occurs with awakening and/or arousal and a high span for the remainder of the 24-hour period during wakefulness, increased activity, or work (White, 1996; Weber et al., 1988). Therefore, considering the delayed lag time of about 5 hours, it suggests that patients take the capsules in the bedtime of about 22:00 pm so that the diltiazem will release at about 2 3 am and peak blood concentration appears in morning ( $T_{\max }=11.6 \mathrm{~h}, 360 \mathrm{mg} /$ dose $)$, or patients take the capsules at 8:00 am to allow the peak drug level between 6:00 and 8:00 pm according to patient conditions (Hermida et al., 2007). So the diltiazem hydrochloride delayed-onset sustained-release pellet capsules should be better for the patients to prevent the attack of heart disease in sleeping time.

There had a limitation in this study. This study was conducted mainly in a small number of young healthy subjects (between 19 and 30 years of age) who did not receive additional medications or tobacco. The study population cannot be representative population of patients totally who might be treated with this medication or with tobacco or alcohol. Meanwhile, the drug interactions potentially were not assessed, and the influence of co-morbid conditions (e.g. motility disorders, malabsorption disorders and achlorhydria) on other aspects of pharmacokinetics could not be accounted for either.

\section{CONCLUSIONS}

The present study suggested that diltiazem hydrochloride delayed-onset sustained-release pellet capsules possessed marked characteristics of delayed and controlled release. From the PK analysis, the pellets administrated showed delayed release time in about 5 hours which will comply with the chronopharmacology. The sustained release pellets capsules could be orally administrated without regard to the food factor.

\section{ACKNOWLEDGEMENT}

This work was supported by National Natural Science Foundation of China (No. 81240105), China Postdoctoral Science Fund (No. 20080430856) and High educated talents fund of Xinxiang Medical University (No. 100778), Hunan province combining achievement transformation project (No. 2009XK6020) and a grant from Clinical Medical College of Yangzhou University and Hunan KAMP Institute for Medical Reaserch.

The authors have no conflicts of interest that are directly relevant to the content of this study.

\section{REFERENCES}

BERTERA, F.M.; MAYER, M.A.; OPEZZO, J.A.; TAIRA, C.A.; HÖCHT, C. Increased sensitivity to diltiazem hypotensive effect in an experimental model of high-renin hypertension. J. Pharm. Pharmacol., v.61, n.1, p.79-87, 2009.

BRITT, B.A. Diltiazem. Can. Anaesth. Soc. J., v.32, n.1, p.3044, 1985. 
CAILLÉ, G.; BOUCHER, S; SPÉNARD, J; LAKHANI, Z; RUSSELL, A; THIFFAULT, J; GRACE, M.G. Diltiazem pharmacokinetics in elderly volunteers after single and multiple doses. Eur. J. Drug Metab. Pharmacokinet., v.16, n.2, p.75-80, 1991.

CHAFFMAN, M.; BROGDEN, R.N. Diltiazem. A review of its pharmacological properties and therapeutic efficacy. Drugs, v.29, n.5, p.387-454, 1985.

CLAAS, S.A.; GLASSER, S.P. Long-acting diltiazem $\mathrm{HCl}$ for the chronotherapeutic treatment of hypertension and chronic stable angina pectoris. Expert. Opin. Pharmacol., v.6, n.5, p.765-776, 2005.

DEY, N.S.; MAJUMDAR, S.; RAO, M.E.B. Multiparticulate drug delivery systems for controlled release. Trop. J. Pharm. Res., v.7, n.3, p.1067-1075, 2008.

EZEUGO, U.; GLASSER, S.P. Clinical benefits versus shortcomings of diltiazem once-daily in the chronotherapy of cardiovascular diseases. Expert. Opin. Pharmacol., v.10, n.3, p.485-491, 2009.

FÄRBOM, P.; WAHLSTRAND, B.; ALMGREN, P.; SKRTIC, S.; LANKE, J; WEISS, L; KJELDSEN, S; HEDNER, T; MELANDER, O. Interaction between renal function and microalbuminuria for cardiovascular risk in hypertension: the nordic diltiazem study. Hypertension, v.52, n.1, p.115$122,2008$.

GLOSSMANN, H.; FERRY, D.R.; LUBBECKE, F; MEWES, R; HOFMANN, F. Identification of voltage operated calcium channels by binding studies: differentiation of subclasses of calcium antagonist drugs with ${ }^{3} \mathrm{H}$-nimodipine radioligand binding. J. Recept. Res., v.3, n.1-2, p.177-190, 1980.

HEKMATARA, T.; REGDON, G.; SIPOS, P; ERÖS, I.; PINTYE-HÓDI, K. Thermoanalytical study of microspheres containing diltiazem hydrochloride. J. Therm. Anal. Calorim., v.86, n.2, p.287-290, 2006.

HERMIDA, R.C.; AYALA, D.E.; CALVO, C.; PORTALUPPI, F.; SMOLENSKY, M.H. Chronotherapy of hypertension: Administration-time-dependent effects of treatment on the circadian pattern of blood pressure. Adv. Drug Deliv. Rev., v.59, n.9-10, p.923-939, 2007.
HÖGLUND, P.; NILSSON, L.G. Liquid chromatographic determination of diltiazem and its metabolites using transisomers as internal standards, with dynamic modification of the solid phase by addition of an amine to the mobile phase. J. Chromatography B, v.414, n.1, p.109-120, 1987.

HOSSACK, K.F.; BRUCE, R.A. Improved exercise performance in persons with stable angina pectoris receiving diltiazem. J. Am. Coll. Cardiol., v.47, n.1, p.95-101, 1981.

LEFEBVRE, M.; LACASSE, Y.; SPÉNARD, J; GEADAH, D.; MOISAN, R; GOSSARD, D.; LANDRIAULT, H.; DU SOUICH, P.; CAILLÉ, G. Pharmacokinetics and pharmacodynamics of a slow-release formulation of diltiazem after the administration of a single and repeated doses to healthy volunteers. Biopharm. Drug Dispos., v.15, n.3, p.227-242, 1994.

MAZZO, D.J.; OBETZ, C.L.; SHUSTER, J. Diltiazem hydrochloride, in analytical profiles of drug substances. California: Academic Press, 1994. v.23, p.53-98.

MURATA, K.; YAMAHARA, H.; KOBAYASHI, M.; NODA, K.; SAMEJIMA, M. Pharmacokinetics of an oral sustainedrelease diltiazem preparation. J. Pharm. Sci., v.78, n.11, p.960-963, 1989.

OCHS, H.R.; KNÜCHEL, M. Pharmacokinetics and absolute bioavailability of diltiazem in humans. J. Mol. Med., v.62, n.7, p.303-306, 1984.

PORTALUPPI, F.; MANFREDINI, R.; FERSINI, C. From a static to a dynamic concept of risk: the circadian epidemiology of cardiovascular events. Chronobiol. Int., v.16, n.1, p.33-49, 1999.

ROBERTS, D.; HONCHARIK, N.; SITAR, D.S.; TENENBEIN, M. Diltiazem overdose: pharmacokinetics of diltiazem and its metabolites and effect of multiple dose charcoal therapy. Clin. Toxicol., v.29, n.1, p.45-52, 1991.

SCHOLZ, H. Pharmacological aspects of calcium channel blockers. Cardiovasc. Drug Ther., v.10, n.3, p.869-872, 1997.

SISTA, S.; LAI, J.C.; ERADIRI, O.; ALBERT, K.S. Pharmacokinetics of a novel diltiazem HCL extendedrelease tablet formulation for evening administration. $J$. Clin. Pharmacol., v.43, n.10, p.1149-1157, 2003. 
SMOLENSKY, M.H.; PEPPAS, N.A. Chronobiology, drug delivery, and chronotherapeutics. Adv. Drug Deliv. Rev., v.59, n.9-10, p.828-51, 2007.

SULTANA, N.; ARAYNE, M.S.; SHAFI, N.; SIDDIQUI, F.A.; HUSSAIN, A. Development of a RP-HPLC method for the simultaneous analysis of diltiazem and statin: Application in pharmaceuticals and human serum. Anal. Methods, v.2, n.10, p.1571-1576, 2010.

THÉROUX, P.; TAEYMANS, Y.; MORISSETTE, D.; BOSCH, X.; PELLETIER, G.B.; WATERS, D.D. A randomized study comparing propranolol and diltiazem in the treatment of unstable angina. J. Am. Coll. Cardiol., v.5, n.3, p.717-722, 1985.

TURNER, S.W.; JUNGBLUTH, G.L.; KNUTH, D.W. Effect of concomitant colestipol hydrochloride administration on the bioavailability of diltiazem from immediate- and sustained-release formulations. Biopharm. Drug Dispos., v.23, n.9, p.369-377, 2002.

VERGHESE, C.; SMITH, M.S.; AANONSEN, L.; PRITCHETT, E.L.; SHAND, D.G. High-performance liquid chromatographic analysis of diltiazem and its metabolite in plasma. J. Chromatogr. B, v.272, n.1, p.149$155,1983$.

WEBER, M.A.; CHEUNG, D.G.; GRAETTINGER, W.F.; LIPSON, J.L. Characterization of antihypertensive therapy by whole-day blood pressure monitoring. J. Nepal. Med. Assoc., v.259, n.2, p.3281-3285, 1988.
WEINER, D.A.; CUTLER, S.S.; KLEIN, M.D. Efficacy and safety of sustained-release diltiazem in stable angina pectoris. Am. J. Cardiol., v.57, n.1, p.6-9, 1986.

WEIR, M.R. Diltiazem: ten years of clinical experience in the treatment of hypertension. J. Clin. Pharmacol., v.35, n.3, p.220-232, 1995.

WHITE, W.B. A chronotherapeutic approach to the management of hypertension. Am. J. Hypertens., v.9, n.4, p.29S-33S, 1996.

YEUNG, P.K.; HUNG, O.R.; POLLAK, P.T.; KLASSEN, G.A. Pharmacokinetics and hemodynamic effects of diltiazem in healthy volunteers: comparing resting with the effect of exercise. Int. J. Clin. Pharm. Ther., v.37, n.8, p.413-416, 1999.

ZARGH, A.; SHAFAATI, A.; FOROUTAN, S.M.; KHODDAM, A. A simple and rapid HPLC method for the determination of atorvastatin in human plasma with UV detection and its application to pharmacokinetic studies. Arznei.-Forschung, v.55, n.8, p.451-454, 2005.

ZHANG, H.Y.; LIAO, P.; WANG, J.J.; YU, D.E.J.; SOONG, T.W. Alternative splicing modulates diltiazem sensitivity of cardiac and vascular smooth muscle $\mathrm{Ca}$ (v) 1.2 calcium channels. Brit. J. Pharmacol., v.160, n.7, p.1631-1640, 2010.

Received for publication on $07^{\text {th }}$ February 2012 Accepted for publication on $06^{\text {th }}$ November 2012 